Vol. 10. No. 1. Tahun 2022

\title{
DAMPAK PANDEMI COVID -19 TERHADAP KEUNTUNGAN DAN EFISENSI USAHA PETERNAKAN AYAM RAS PETELUR DI DESA PRINGGAJURANG KECAMATAN MONTONG GADING KABUPATEN LOMBOK TIMUR”.
}

\author{
${ }^{1}$ Muhamad Sarlan, ${ }^{2}$ Murah \\ ${ }^{1}$ Fakultas Pertanian Universitas Gunung Rinjani-Universitas Gunung Rinjani \\ ${ }^{2}$ Fakultas Keguruan dan Ilmu Pendidikan-Universitas Gunung Rinjani \\ ${ }^{1}$ Muhamadsarlan@gmail.com, \\ 2yusufmurah@gmail.com
}

\begin{abstract}
Abstrak
Tujuan penelitian ini adalah untuk mengetahui keuntungan Usaha ayam ras petelur sebelum dan selama covid -19 di Desa Pringgajurang Kecamatan Montong Gading Kabupaten Lombok Timur dan Untuk mengetahui Efisensi Usaha Ayam Ras petelur sebelum dan selama covid 19 di Desa Pringgajurang Kecamatan Montong Gading Kabupaten Lombok Timur. Metode penentuan daerah penelitian dilakukan menggunakan metode purposive (sengaja). Daerah yang dipilih adalah Desa Pringgajurang Kecamatan Montong Gading Kabupaten Timur. Alasan memilih desa tersebut sebagai daerah penelitian adalah karena desa ini merupakan desa yang memiliki Populasi ayam ras petelur yang paling besar diantara desa lainnya di Kecamatan Montong Gading. Hasil penelitian menunjukkan rata rata keuntungan yang diperoleh peternak sebesar Rp. 92.314.700 dengan efisiensi sebesar 1,278 sebelum covid-19 dan keuntungan sebesar Rp.12.068.010 dengan efisiensi sebesar 1,029 selama covid-19. Selanjutnya hasil penelitian juga menunjukkan bahwa covid-19 berdampak terhadap pendapatan dan efisiensi usaha ternak ayam ras petelur dibuktikan dengan hasil t- hitung sebesar 6.841 untuk pendapatan, dan t-hitung sebesar 7,381 untuk efisensi dibandingkan dengan sig.(2-tiled) sebesar 0.000 atau lebih kecil dari alfa $(0,05)$. Sehingga disimpulkan bahwa covid-19 berdampak sangat nyata terhadap keuntungan dan efisiensi usaha ayam ras petelur di desa Pringgajurang Kecamatan Montong Gading Kabupaten Lombok Timur.
\end{abstract}

Kata Kunci: Covid-19, Dampak, Keuntungan, Produksi telur.

\begin{abstract}
The purpose of this study was to determine the profit of laying hens business before and during covid-19 in Pringgajurang Village, Montong Gading District, East Lombok Regency and to determine the Efficiency of Laying Chicken Business before and during covid 19 in Pringgajurang Village, Montong Gading District, East Lombok Regency. The method of determining the research area was carried out using the purposive method (deliberately). The selected area is Pringgajurang Village, Montong Gading District, East Regency. The reason for choosing this village as the research area is because this village has the largest population of laying hens among other villages in Montong Gading District. The results showed that the average profit earned by farmers was Rp. 92,314,700 with an efficiency of 1,278 before covid-19 and a profit of Rp. 12,068,010 with an efficiency of 1,029 during covid-19. Furthermore, the results of the study also show that Covid-19 has an impact on income and business efficiency of laying hens as evidenced by the results of a t-count of 6,841 for income, and a t-count of 7.381 for efficiency compared to sig.(2-tiled) of 0.000 or smaller than alpha (0.05). So it was concluded that COVID-19 had a very real impact on the profits and efficiency of the laying hens business in Pringgajurang Village, Montong Gading District, East Lombok Regency.
\end{abstract}

Keywords: Covid-19, Impact, Profit, Egg production.Abstract 
Vol. 10. No. 1. Tahun 2022

\section{PENDAHULUAN}

Peternakan merupakan sub sektor pertanian yang sangat penting peranannya dalam menjaga ketahanan pangan, karena pangan yang berasal dari hewani merupakan sumber protein yang sangat penting dalam memenuhi kebutuhan gizi masyarakat. (Warsito, 2010).

Sejalan dengan semakin meningkatanya jumlah penduduk, tingkat pendidikan, perubahan gaya hidup masyarakat, dan kesadaran akan pentingnya gizi masyarakat, permintaan akan produk-produk peternakan seperti, daging, susu, dan telur, terus mengalami peningkatan (Rusli, 2011).

Pengembangan ayam ras petelur di masa yang akan datang di Kabupaten Lombok Timur memiliki prospek yang sangat cerah. Hal ini terlihat dari sisi permintaan (Demand) dan sisi penawaran (Supply). Dari sisi permintaan dapat dilihat dari jumlah penduduk yang makin bertambah, diikuti dengan income perkpita masyarakat yang semakin meningkat. Jika pendapatan meningkat maka konsumsi telur juga akan meningkat.

Populasi ayam ras petelur di kabupaten Lombok Timur dari tahun 2015 -2020 terus mengalami peningkatan. Berdasarkan data Badan Pusat Statistik (BPS), Propinsi Nusa Tenggara Barat tercatat sebanyak 24.396 ekor pada tahun 2015, sebanyak 23.845 ekor tahun 2016, sebanyak 117.124 ekor tahun 2017, sebanyak 251.772 tahun 2018, sebanyak 431.142 ekor pada tahun 2019 dan sebanyak 522.872 ekor pada tahun 2020. Berdasarkan data diatas terlihat bahwa jumlah populasi ayam ras petelur selama 6 tahun terakhir meningkat rata-rata sebesar 112,67 persen pertahun.

Pringgajurang merupakan salah satu Desa sentra produksi ayam ras petelur yang ada di Kecamatan Montong Gading Kabupaten Lombok Timur, memiliki keunggulan dengan desa-desa lainnya diantaranya, perkembangan jumlah populasi ayam ras terus menerus meningkat dari tahun ke tahun, lokasi usaha yang cukup potensial serta telah melakukan kegiatan usaha peternakan ayam ras petelur dengan cukup professional. Keunggulankeunggulan inilah yang setidaknya dapat memberikan kontinyuitas usaha tetap berjalan dan dapat memberikan keuntungan dalam usaha ayam ras petelur.

Sejalan dengan semakin meningkatnya perkembangan agribisnis ayam ras petelur, pada awal tahun 2020 tepatnya bulan maret, pandemi covid 19 telah melanda berbagai daerah di Indonesia, telah berdampak terhadap berbagai sektor terutama ekonomi. Sektor perekonomian yang terdampak salah satunya bidang usaha peternakan ayam petelur. Kondisi ini mendorong permintaan terhadap produk peternakan seperti telur makin menurun. Perubahan permintaan terhadap telur ayam ras petelur, menjadi lebih sensitive terhadap perubahan pendapatan masyarakat.

Sejak diberlakukannya Pemberlakuan Pembatasan Kegiatan Masyarakat (PPKM), di berbagai daerah di Indonesia berdampak terhadap permintaan produk-produk yang dihasilkan dari unggas, terutama telur ayam ras petelur, sementara disatu sisi, pakan ternak seperti jagung, dedak, konsentrat dan vitamin sebagai penyusun komponen pakan ayam ras petelur terus menerus mangalami kenaikan harga. Sementara harga telur relatif tetap bahkan cenderung turun. Kondisi inilah yang menyebabkan tingkat pendapatan peternak ayam ras petelur menjadi menurun. Berdasarkan hal tersebut diatas, maka dilakukan penelitian yang berjudul "Dampak Pandemi Covid 19 terhadap keuntungan dan efisensi usaha peternakan ayam ras petelur di Desa Pringgajurang Kecamatan Montong Gading Kabupaten Lombok Timur".

\section{Rumusan Masalah}

Berdasarkan uraian latar belakang, maka masalah penelitian diidentifikasi sebagai berikut:

1. Bagaimana dampak Pandemi Covid-19 terhadap keuntunganUsaha ayam ras petelur di Desa Pringgajurang Kecamatan Montong Gading Kabupaten Lombok Timur?

2. Bagaimana dampak Pandemi Covid-19 terhadap Efisiensi Usaha Ayam ras Petelur di Desa Pringgajurang Kecamatan Montong Gading Kabupaten Lombok Timur?

\section{Tujuan Penelitian}

Adapun tujuan penelitian ini adalah sebagai berikut:

1. Untuk mengetahui keuntungan Usaha 
ayam ras petelur sebelum dan selama covid -19 di Desa Pringgajurang Kecamatan Montong Gading Kabupaten Lombok Timur

2. Untuk mengetahui Efisensi Usaha Ayam Ras petelur sebelum dan selama covid 19 di Desa Pringgajurang Kecamatan Montong Gading Kabupaten Lombok Timur.

\section{METODE PENELITIAN}

\section{Metode Penentuan Daerah Penelitian}

Metode penentuan daerah penelitian dilakukan menggunakan metode purposive (sengaja). Daerah yang dipilih adalah Desa Pringgajurang Kecamatan Montong Gading Kabupaten Timur. Alasan memilih desa tersebut sebagai daerah penelitian adalah karena desa ini merupakan desa yang memiliki Populasi ayam ras petelur yang paling besar diantara desa lainnya di Kecamatan Montong Gading.

\section{Metode Pengambilan Sampel}

Metode yang digunakan pada penelitian ini adalah metode sensus. Metode sensus adalah metode dengan mengambil sampel secara keseluruhan. Karena hanya ada 20 orang peternak ayam petelur di Desa Pringgajurang maka seluruhnya dijadikan sebagai responden penelitian.

\section{Metode Pengumpulan Data}

Data yang dikumpulkan dalam penelitian ini adalah data primer dan data sekunder. Data primer diperoleh langsung dari objek yang diteliti melalui hasil wawancara dan kuisioner yang bertujuan untuk mengetahui pendapatan usaha ternak ayam ras petelur sebelum dan selama Pandemi Covid-19. Sedangkan data sekunder diperoleh dari berbagai sumber seperti literatur, jurnal, skripsi, buku, Badan Pusat Statistik dan Badan Penyuluhan Pertanian.

Adapun data yang dikumpulkan sebagai data sebelum masa Pandemi Covid19 adalah sebelum Maret 2020 dan data untuk selama masa Pandemi Covid-19 adalah setelah Maret 2020, hal tersebut dikarenakan oleh Maret 2020 merupakan awal dari merebaknya Pandemi Covid-19 di Indonesia sehingga menjadikannya sebagai titik penentu antara masa sebelum dan selama pandemic.

\section{ANALISIS DATA}

1. Untuk mengetahui keuntungan yang diterima oleh peternak ayam ras petelur dengan formula sebagai berikut:

$\pi=\mathrm{TR}-\mathrm{TC}$.

Keterangan:

$\pi=$ Keuntungan peternak ayam ras petelui (Rp)

$\mathrm{TR}=$ Total Revenue/total penerimaan peternak ayam ras petelur $(\mathrm{Rp})$

$\mathrm{TC}=$ Total Cost/total pengeluaran peternak ayam ras petelur $(\mathrm{Rp})$

2. Untuk mengetahui Efisensi Usaha Ayam ras Petelur sebelum dan selama covid 19 digunakan rumus :

$\mathrm{R} / \mathrm{C}$ ratio $=\mathrm{TR} / \mathrm{TC}$

Keterangan :

TR : Total penerimaan

TC : Total Biaya

Kriteria Pengujian :

$\mathrm{R} / \mathrm{C}$ ratio $>1$ maka usaha sudah efisien

$\mathrm{R} / \mathrm{C}$ rati0 $<1$ maka usaha belum efisien.

3. Selanjutnya untuk menjawab hipotesis 1 dan hipotesis 2 , metode yang digunakan dalam penelitian ini adalah metode komparatif dengan menggunakan uji beda dengan sampel berhubungan (Paired sample t-Test) dengan rumus:

$$
t=\frac{\bar{X}_{D}-\mu_{0}}{s_{D} / \sqrt{n}} .
$$

Dimana:

$$
\begin{aligned}
& \bar{X}_{d}=\frac{\sum D}{n} \\
& s_{d}=\sqrt{\frac{1}{n-1}\left\{\sum D^{2}-\frac{\left(\sum D\right)^{2}}{n}\right\}}
\end{aligned}
$$

Keterangan:

$\mathrm{D}=$ Selisih $\mathrm{X} 1$ dan $\mathrm{X} 2(\mathrm{X} 1-\mathrm{X} 2)$

$\mathrm{n}=$ Jumlah Sampel $\mathrm{X}$ bar $=$ Rata-rata

$\mathrm{S} \mathrm{d}=$ Standar Deviasi dari $\mathrm{d}$.

Adapun hipotesis dari rumus uji beda dua sampel berpasangan dengan membandingkan $\mathrm{t}$ hitung dengan $\mathrm{t}$ tabel adalah sebagai berikut:

Jika nilai $\mathrm{t}$ hitung $>\mathrm{t}$ tabel, maka $\mathrm{H} 0$ ditolak, H1 diterima. 
Jika nilai t hitung $\leq \mathrm{t}$ tabel, maka $\mathrm{H} 0$ diterima, H1 ditolak.

Jika nilai signifikansi $>\alpha ; \mathrm{H} 0$ diterima, $\mathrm{H} 1$ ditolak, $(\alpha=0,05)$.

Jika nilai signifikansi $\leq \alpha$; H0 ditolak, H1 diterima, $(\alpha=0,05)$.

Uji perbedaan rata-rata dua sampel berpasangan atau uji paired sample $t$ test digunakan untuk menguji apakah terdapat perbedaan rata-rata untuk dua sampel bebas (independent) yang berpasangan (perbedaan pendapatan dan efisiensi usaha ternak ayam ras petelur sebelum dan selama Pandemi Covid-19). Adapun yang dimaksud berpasangan adalah data pada sampel kedua merupakan perubahan atau perbedaan dari data sampel pertama atau dengan kata lain sebuah sampel dengan subjek sama mengalami dua perlakuan.

Hipotesis yang digunakan dalam penelitian ini adalah sebagai berikut:

H0: Tidak ada perbedaan yang nyata keuntungan dan efisnensi peternak ayam ras petelur sebelum dan selama Pandemi Covid19.

H1: Ada perbedaan yang nyata keuntungan dan efisensi peternak ayam ras petelur sebelum dan selama Pandemi Covid-19.

\section{HASIL DAN PEMBAHASAN.}

Pandemi Covid-19 yang mulai menyebar di Indonesia sejak Maret 2020 menyebabkan dampak yang cukup besar bagi masyarakat di Kabupaten Lombok Timur, tak terkecuali masyarakat yang ada di Desa Pringgajurang Kecamatan Montong Gading. Desa ini mempunyai produksi Telur ayam ras terbesar di antara desa lain di Kecamatan Montong gading, sehingga menjadikannya sebagai desa sentra produksi Teluar ayam ras. Pandemi Covid-
19 membawa dampak pada produksi, harga dan biaya produksi usaha ternak ayam ras, yang kemudian berdampak pada penurunan penerimaan dan pendapatan peternak di Desa Pringgajurang.

Berdasarkan hasil penelitian di lapangan melalui proses wawancara dengan peternak ayam ras petelur, Pandemi Covid19 memiliki dampak terhadap usaha ternak ayam ras petelur di Desa Pringgajurang.. Hasil analisis data sebagai berikut:

\section{Biaya Produksi.}

Biaya produksi yang dikeluarkan oleh peternak ayam ras petelur di Pringgajurang Kecamatan Montong gading Kabupaten Lombok Timur, dibagi menjadi dua, yaitu biaya tetap dan biaya tidak tetap.

\section{Biaya Tetap}

Biaya tetap (fixed cost) adalah biaya yang dikeluarkan oleh usaha ternak ayam ras petelur, yang penggunaannya tidak habis dipakai dalam satu masa produksi. Besar kecilnya biaya produksi tersebut tidak dipengaruhi oleh banyaknya produksi yang dihasilkan oleh usaha ternak ayam ras petelur, namun biaya ini harus dikeluarkan. Pada usaha ternak ayam ras petelur di Lombok Timur, yang termasuk biaya tetap (fixed cost) adalah biaya pajak tanah, , biaya penyusutan peralatan kandang seperti tempat pakan ayam, tempat minum ayam, sekop, cangkul, hand sprayer, drum plastic, mesin air, mesin jenset dan baiaya penyusutan bangunan kandang .. Biaya tetap yang harus dikeluarkan oleh usaha ternak ayam ras petelur berupa pajak tanah yaitu sebesar Rp. 11.300 setiap tahunnya, biaya penyusutan peralatan kandang sebesar Rp. 3.436 .400 per tahun dan biaya penyusutan bangunan kandang sebesar Rp. 6.780 .000 per tahun. Untuk lebih jelasnya dapat dilihat pada tabel berikut :

Tabel 1. Biaya Tetap Usaha Ternak Ayam Ras Petelur di Kecamatan Montong Gading tahun 2020

\begin{tabular}{|l|l|r|}
\hline No. & Jenis Biaya Tetap & \multicolumn{2}{|c|}{ Biaya Produksi (Rp.) } \\
\hline 1 & Pajak & 11.300 \\
\hline 2. & Penyusutan Peralatan Kandang & 3.436 .400 \\
\hline 3. & Penyusutan Bangunan Kandang & 6.780 .000 \\
\hline & Jumlah & 10.256 .400 \\
\hline
\end{tabular}




\section{Biaya Variabel (Variabel Cost) Usaha Ternak Ayam Ras Petelur Tahun 2020}

Biaya variabel (variabel cost) adalah biaya yang besar kecilnya sangat tergantung kepada skala produksi. Biaya yang tergolong biaya variabel (variabel cost) pada usaha ternak ayam ras petelur adalah biaya sarana produksi yang terdiri atas, biaya pakan, biaya vaksin, biaya tenaga kerja, biaya listrik dan biaya penyusutan indukan ayam (penyusutan babon).

Berikut ini merupakan komponen total biaya variabel pada usaha ternak ayam ras petelur satu tahun periode produksi sebelum dan selama Covid 19 pada tahun 2020 di Kabupaten Lombok Timur.

Tabel 2. Biaya Variabel pada Usaha ternak ayam ras petelur sebelum dan selama Covid 19 di Desa Pringgajurang Kecamatan Montong Gading Kabupaten Lombok Timur Tahun 2020.

\begin{tabular}{|l|l|r|r|}
\hline No. & Jenis Biaya Variabel & $\begin{array}{c}\text { Biaya Produksi } \\
\text { Sebelum Covid 19 } \\
\text { (Rp.) }\end{array}$ & $\begin{array}{c}\text { Biaya Produksi } \\
\text { Selama Covid 19 } \\
\text { (Rp.) }\end{array}$ \\
\hline 1 & Biaya Pakan & 238.546 .800 & 294.116 .400 \\
\hline 2 & Biaya Tenaga Kerja & 20.480 .000 & 20.480 .000 \\
\hline 3 & Biaya obat, vitamin dan Vaksin & 2.675 .000 & 2.785 .000 \\
\hline 4 & Biaya Penyusutan Babon & 64.033 .000 & 71.566 .000 \\
\hline 5 & Biaya EggTray & 7.020 .000 & 8.424 .000 \\
\hline 6 & Biaya Listrik & 600.000 & 360.000 \\
\hline & Jumlah & 333.342 .800 & 397.731 .400 \\
\hline
\end{tabular}

Berdasarkan Tabel 2. di atas, menunjukkan bahwa total biaya variabel yang dikeluarkan oleh usaha ternak ayam ras petelur desa Pringgajurang Kecamatan Montong Gading dalam satu tahun produksi sebesar Rp.333.342.800 sebelum covid 19 dan sebesar Rp. 397.731 .400 selama covid 19. Biaya variabel terbesar yang dikeluarkan oleh usaha ternak ayam ras petelur adalah biaya pakan yaitu sebesar Rp. 238.546.800 sebelum Covid 19 dan sebesar Rp. 294.116.400 selama covid 19. Urutan kedua adalah biaya penyusutan babon sebesar Rp. 64.003.000 sebelum covid 19 dan Rp. 71.566.000., selama covid 19. Urutan ketiga adalah biaya tenaga kerja sebesar Rp. 20.400.000 baik sebelum covid 19 maupun selama covid 19. Urutan ke empat biaya pembelian tray sebesar Rp. 7.020.000 sebelum covid 19 dan Rp. 8.424.000 selama covid 19. Urutan kelima biaya pembelian vitamin, vaksin dan obatobatan sebesar Rp. 2.675.000 sebelum covid 19 dan Rp. 2.785.000 selama covid 19. Dan yang terakhir adalah biaya listrik sebesar Rp.600.000 sebelum covid 19 dan sebesar

Rp. 360.000 selama covid 19.

\section{Biaya Total Usaha Ternak Ayam Ras Petelur sebelum dan selama covid 19 di desa Pringgajurang Kecamatan Montong Gading Kabupaten Lombok Timur tahun 2020}

Biaya total merupakan penjumlahan dari biaya tetap (fixed cost) total dan biaya variabel (variabel cost) total pada usaha ternak ayam ras petelur yang dikeluarkan dalam satu tahun pemeliharaan. Biaya tetap (fixed cost) total yang dikeluarkan oleh Usaha ternak ayam ras petelur terdiri dari biaya pajak tanah, biaya penyusutan peralatan dan bangunan ditambah dengan biaya variabel (variabel cost) yang terdiri atas biaya biaya pakan, biaya vaksin, biaya listrik, biaya Tenaga Kerja, Biaya pembelian EggTeray, biaya penyusutan babon . jumlah Biaya tetap (fixed cost) dan biaya Variabel usaha ternak ayam ras petelur adalah sebesar Rp. 331.232.800 sebelum covid 19 dan sebesar Rp. 407.987.400., selama covid 19. Gambaran mengenai biaya total dapat dilihat pada Tabel berikut ini :

Tabel 3. Biaya Total Usaha Ternak ayam ras di Desa Pringgajurang Kecamatan Montong Gading Lombok Timur tahun 2020 
Vol. 10. No. 1. Tahun 2022

\begin{tabular}{|l|l|c|c|}
\hline No. & Jenis Biaya & $\begin{array}{c}\text { Jumlah biaya Produksi } \\
\text { sebelum covid } 19 \\
(\mathrm{Rp} .)\end{array}$ & $\begin{array}{c}\text { Jumlah biaya Produksi } \\
\text { selama covid } 19 \\
(\mathrm{Rp} .)\end{array}$ \\
\hline 1 & Biaya Tetap & 10.256 .000 & 10.256 .000 \\
\hline 2 & Biaya variabel & 333.342 .800 & 397.731 .400 \\
\hline & Jumlah & 343.598 .800$. & 407.987 .400 \\
\hline
\end{tabular}

\section{Penerimaan Usaha Ternak Ayam Ras Petelur}

Usaha ternak ayam ras petelur mulai berproduksi untuk menghasilkan telur pada umur ayam 18 minggu (132 hari), dan akan menurun produksinya setelah ayam berumur 80 minggu (560 hari). Setelah umur 80 minggu peternak ayam akan mengafkir (menjual) ayam tersebut dengan kisaran antara 40 persen sampai 50 persen dari harga awal indukan. Penerimaan hasil Usaha ternak ayam ras petelur di desa Pringgajurang Kecamatan Montong Gading Kabupaten Lombok Timur dalam 1 (satu) hari menghasilkan sekitar 920 butir atau setara dengan $51,1 \mathrm{~kg}$ per hari. Sehingga dalam 1 (satu) tahun pemeliharaan ( 365 hari) menghasilkan sekitar 335.800 butir atau $18.651,5 \mathrm{~kg}$ per tahun telur ayam ras yang dijual dengan harga 1 (satu) Kg (18 butir telur) telur ayam ras sebesar Rp. 21.000. per $\mathrm{kg}$, sebelum covid 19 dan sebesar 20. 940 per $\mathrm{kg}$ selama covid 19. Sehingga total penjualan telur sebanyak Rp. 391.681 .500 sebelum covid 19, dan sebesar Rp. 390.562.410 selama covid 19. Usaha ternak ayam ras petelur juga mendapatkan penerimaan dari produk sampingan berupa ayam afkir sebanyak 1.017 ekor yang dijual dengan harga Rp. 47.000 per ekor sebelum covid 19 dan Rp.43.500 selama covid 19, untuk satu periode produksi selama 18 bulan. Sehingga dalam satu tahun nilai produksi usaha sampingan berupa ayam afkir sebesar Rp. 31.866.000 sebelum covid 19 dan sebesar Rp. 29.493.000 selama covid 19.

Untuk melihat penerimaan usaha ternak ayam ras petelur sebelum dan selama covid 19 lebih jelasnya dapat dilihat pada Tabel berikut ini.

Tabel 4. Penerimaan Usaha Ternak Ayam ras Petelur di Desa Pringgajurang Kecamatan Montong Gading Lombok TImur tahun 2020

\begin{tabular}{|l|l|r|r|}
\hline No. & Jenis penerimaan & Sebelum covid 19 & \multicolumn{1}{|c|}{ Selama covid 19 } \\
\hline 1. & Telur ayam (Rp.) & 391.681 .500 & 390.562 .410 \\
\hline 2 & Ayam afkir (Rp.) & 31.866 .000 & 29.493 .000 \\
\hline & jumlah & 423.547 .500 & 420.055 .410 \\
\hline
\end{tabular}

Sumber : Data Primer diolah

\section{Pendapatan dan Efiisensi Usaha Ternak Ayam Ras Petelur sebelum dan selama covid 19 di Kabupaten Lombok Timur tahun 2020.}

Usaha ternak ayam petelur memilki tujuan untuk mendapatkan pendapatan yang maksimal dengan menggunakan faktor produksi yang optimal. Pendapatan adalah selisih antara penerimaan dikurangi dengan semua biaya yang dikeluarkan. Pendapatan usaha ternak ayam ras petelur selama satu tahun pemeliharaan di Kabupaten Lombok Timur adalah sebesar Rp. 92.314 .700 per tahun sebelum covid 19 dan sebesar Rp. 12.068.010., selama covid 19, Untuk lebih jelasnya dapat dilihat pada Tabel 5. Berikut.

Tabel 5. Penerimaan, Biaya, Pendapatan dan Efisiensi Usaha Ternak Ayam ras Petelur di Desa Pringgajurang Kecamatan Montong Gading Lombok TImur tahun 2020 
Vol. 10. No. 1. Tahun 2022

\begin{tabular}{|l|l|c|c|r|c|}
\hline No. & Waktu/masa & $\begin{array}{c}\text { Penerimaan } \\
\text { (Rp.) }\end{array}$ & $\begin{array}{c}\text { Biaya } \\
\text { (Rp.) }\end{array}$ & $\begin{array}{c}\text { Pendapatan } \\
\text { (Rp.) }\end{array}$ & R/C ratio \\
\hline 1. & Sebelum covid 19 & 423.547 .500 & 331.232 .800 & 92.314 .700 & 1,278 \\
\hline 2. & Selama covid 19 & 420.055 .410 & 407.987 .400 & 12.068 .010 & 1,029 \\
\hline
\end{tabular}

Selanjutnya untuk mengetahui apakah usaha ternak ayam ras petelur efisen, pada tabel diatas juga terlihat bahwa nilai $\mathrm{R} / \mathrm{C}$ ratio sebelum covid sebesar 1,278 dan sebesar 1.029 selama covid 19. Yang berarti bahwa setiap 1 rupiah biaya yang dikeluarkan dalam usaha ternak ayam ras petelur akan diperoleh penerimaan sebesar 1,278 rupiah sebelum covid 19 dan 1,029 rupiah selama covid 19. Hal ini menunjukkan nilai $\mathrm{R} / \mathrm{C}$ ratio yang lebih besar dari satu, yang berarti bahwa usaha ternak ayam ras petelur masih layak untuk diusahakan.

\section{Hasil Analisis Dampak Pandemi Covid- 19 Terhadap Pendapatan dan Efisiensi Usaha Ternak Ayam Ras Petelur di Desa Pringgajurang Kecamatan Montong Gading Kabupaten Lombok Timur Sebelum dan Selama Pandemi Covid-19}

Dari hasil analisis dampak Pandemi Covid-19 terhadap pendapatan peternak dengan menggunakan SPSS uji beda rata rata. dapat dilihat pada tabel 5.berikut:

Tabel 5. Hasil Perbedaan Pendapatan Sebelum dan se4lama Pandemi Covid-19, Usaha Ternak Ayam ras Petelur di Desa Pringgajurang Kecamatan Montong Gading Lombok TImur tahun 2020

\section{Paired Samples Test}

\begin{tabular}{|c|c|c|c|c|c|c|c|c|}
\hline & \multicolumn{5}{|c|}{ Paired Differences } & & & \\
\hline & \multirow{2}{*}{ Mean } & \multirow{2}{*}{$\begin{array}{c}\text { Std. } \\
\text { Deviation }\end{array}$} & \multirow{2}{*}{$\begin{array}{l}\text { Std. Error } \\
\text { Mean }\end{array}$} & \multicolumn{2}{|c|}{$\begin{array}{l}95 \% \text { Confidence Interval } \\
\text { of the Difference }\end{array}$} & & & \\
\hline & & & & Lower & Upper & $\mathrm{t}$ & df & $\begin{array}{c}\text { Sig } \\
(2-\text { tile })\end{array}$ \\
\hline $\begin{array}{l}\text { Keuntunga } \\
\mathrm{n} \text { sebelum } \\
\text { covid19 } \\
\text { Keuntunga } \\
\mathrm{n} \quad \text { setelah } \\
\text { covid19 }\end{array}$ & $8.76758 \mathrm{E} 868$ & 5.73127E6 & $1.28155 \mathrm{E} 6$ & $6.08526 \mathrm{E} 6$ & $1.14499 \mathrm{E} 7$ & 6.841 & 19 & 000 \\
\hline
\end{tabular}

Dari tabel 5. diperoleh nilai $\mathrm{t}$ sebesar 6.841 dengan Sig. (2-tailed) sebesar 0.000 atau lebih kecil dari $\alpha(0,05)$ maka H0: ditolak dan H1: diterima. Sehingga dapat diartikan bahwa terdapat perbedaan yang nyata pendapatan usaha ternak ayam ras petelur sebelum Pandemi Covid-19 dan selama Pandemi Covid-19.

Berdasarkan uraian sebelumnya, penurunan pendapatan disebabkan oleh tingginya kenaikan harga pakan ternak. Hal ini sesuai dengan teori pendapatan usahatani menurut Gustiyana (2004), yaitu yang pertama penerimaan adalah sesuatu yang diperoleh petani dalam usahatani selama satu tahun yang dapat diperhitungkan dari hasil penjualan atau pertukaran hasil produksi yang dinilai dalam rupiah berdasarkan harga persatuan berat, sedangkan pendapatan yaitu keseluruhan harta (uang) yang diperoleh petani dalam satu tahun dikurangi dengan biaya produksi selama proses produksi. Selanjutnya berdasrkan hasil uji statistic dengan menggunakan program SPSS statistic 17.0 dapat dilihat pada tabel 6 berikut:

Tabel 6. Hasil Perbedaan Efisiensi Sebelum dan selama Pandemi Covid-19, Usaha Ternak Ayam ras Petelur di Desa Pringgajurang Kecamatan Montong Gading Lombok TImur tahun 2020

\section{Paired Samples Test}




\begin{tabular}{|c|c|c|c|c|c|c|c|c|}
\hline & \multicolumn{5}{|c|}{ Paired Differences } & & & \\
\hline & \multirow[t]{2}{*}{ Mean } & \multirow{2}{*}{$\begin{array}{l}\text { Std. } \\
\text { Deviat } \\
\text { ion }\end{array}$} & \multirow{2}{*}{$\begin{array}{l}\text { Std. } \\
\text { Error } \\
\text { Mean }\end{array}$} & \multicolumn{2}{|c|}{$\begin{array}{l}\text { 95\% Confidence } \\
\text { Interval of the } \\
\text { Difference }\end{array}$} & & & \\
\hline & & & & Lower & Upper & $\mathrm{t}$ & $\mathrm{df}$ & $\begin{array}{c}\text { Sig } \\
(2-\text { tile })\end{array}$ \\
\hline $\begin{array}{l}\text { Ratio cost } \\
\text { sebelum } \\
\text { covid } 19 \\
\text { Rasio cost } \\
\text { setelah } \\
\text { covid } 19\end{array}$ & 8.76758E868 & .13632 & .03038 & .161620 & .28880 & 7.381 & 19 & .000 \\
\hline
\end{tabular}

Selanjutnya dari tabel 6. diperoleh nilai $\mathrm{t}$ sebesar 7.381dengan Sig. (2-tailed) sebesar 0.000 atau lebih kecil dari $\alpha(0,05)$ maka H0: ditolak dan H1: diterima. Sehingga dapat diartikan bahwa terdapat perbedaan yang nyata antara efisiensi usaha ternak ayam ras petelur sebelum Pandemi Covid-19 dan selama Pandemi Covid-19.

\section{SIMPULAN DAN SARAN}

Hasil penelitian menyimpulkan bahwa terdapat perbedaan yang nyata antara keuntungan dan efisensi usaha ayam ras petelur di desa Pringgajurang Kecamatan Montong Gadimg Kabupaten Lombok Tiumr sebelum dan selamaPandemi Covid-19.

Melihat peran sector pertanian khususnya bidang peternakan terhadap perekonomian darerah, pemerintah hendaknya melakukan langkah langkah dalam penanganan dan membuat regulasi dalam menghadapi covid 19, dengan mengoptimalkan potensi dibidang pertanian khususnya bidang peternakan.

Demikian pula dengan peternak hendaknya dapat melakukan inovasi baru dengan cara membuat ransum sendiri, agar efisiensi sarana produksi terutama pakan ternak yang terus menerus mengalami peningkatan dapat ditekan.

\section{DAFTAR PUSTAKA}

Ardilawati, R 2012. Analisis Usaha Peternakan Ayam Petelur Pada Peternakan Ayam petelur Cihaur, Maja , Majalengka , Jawa Barat.

Chandra, 2001. Pendapatan Usaha Pernakan Ayam Ras (Studi Kasus di Kecamatan Bejen, Kabupataen Temanggun).

BPS Kabupaten Lombok Timur, 2020. Lombok Timur dalam Angka, 2020

Rustan.2003, Analisis Pendapatan dan Efisiensi Usaha Ayam Petelur Di Kabupaten Wonosobo. Surya Agritama

Rasyaf, M. 2003.Faktor-faktor Produksi Telur. Jakarta: Penebar Swadaya.

Rasyaf, M. 2007. BeternakAyam Broiler. Jakarta: Penebar Swadaya 